\title{
Criminal Recidivism of Illegal Pornography Offenders in the Overall Population -A National Cohort Study of 4612 Offenders in Switzerland
}

\author{
Anne Goller ${ }^{\text {* }}$, Roland Jones ${ }^{2,3}$, Volker Dittmann', Pamela Taylor ${ }^{2}$, Marc Graf ${ }^{1}$ \\ ${ }^{1}$ Forensic Psychiatric Hospital, Psychiatric Hospital of the University of Basel, Basel, Switzerland \\ ${ }^{2}$ Section of Forensic Psychiatry, Department of Psychological Medicine and Neurology, Cardiff University, \\ Cardiff, UK \\ ${ }^{3}$ Wales and Llanarth Court Hospital, Raglan, UK \\ ${ }^{4}$ Institute of Legal Medicine, University of Basel, Basel, Switzerland \\ Email: *Anne.Goller@upkbs.ch, jonesrm6@cf.ac.uk, Volker.Dittmann@unibas.ch, TaylorPJ2@cf.ac.uk, \\ Marc.Graf@upkbs.ch
}

Received 25 November 2015; accepted 13 February 2016; published 16 February 2016

Copyright (C) 2016 by authors and Scientific Research Publishing Inc.

This work is licensed under the Creative Commons Attribution International License (CC BY).

http://creativecommons.org/licenses/by/4.0/

(c) (i) Open Access

\section{Abstract}

Convictions for taking, possessing and distributing pornographic photographs of children have increased with the growing use of the Internet. Previous studies of any progression to contact offences have been small scale and only a few of these have included an investigation of subsequent reconvictions for use of illegal and especially of child pornography. The aims of the present study are to compare reconviction rates among illegal pornography offenders with and without previous child contact offences. The former are referred to as "dual offenders". This study is a national cohort study of all individuals in Switzerland convicted of an illegal pornography offence since 1973 and was followed-up until $1^{\text {st }}$ November 2008 . Reconvictions were ascertained using criminal records from the Federal Office of Justice of Switzerland, leading to a total of 4612 offenders, consisting of 4249 illegal pornography offenders and 363 dual offenders. Comparison of 3-year reconviction rates showed that only $0.2 \%$ of the illegal pornography offenders were convicted of contact child sex offences, whereas $2.6 \%$ of the dual offenders were reconvicted. The illegal pornography offenders were also significantly less likely to be convicted of further pornography offences, or indeed other sexual offences. The very low "progression rate" among illegal pornography offenders to contact child sexual offences, and their low rate of even repeat pornography offences suggests that community sentences remain appropriate. It is important, however, to bear in

\footnotetext{
${ }^{*}$ Corresponding author.
}

How to cite this paper: Goller, A., Jones, R., Dittmann, V., Taylor, P., \& Graf, M. (2016). Criminal Recidivism of Illegal Pornography Offenders in the Overall Population-A National Cohort Study of 4612 Offenders in Switzerland. Advances in Applied Sociology, 6, 48-56. http://dx.doi.org/10.4236/aasoci.2016.62005 
mind that conviction rates tend to underestimate the true offending rates, and that with greater access to the Internet, characteristics of pornography users may change over time.

\title{
Keywords
}

\author{
Sex Offenders, Illegal Pornography, Recidivism, Child Sexual Offence, Internet
}

\section{Introduction}

Generating, possessing or distributing pornographic images of children is a criminal offence in most countries. Since the advent of digital technology, the means to acquire, store, duplicate and distribute photographic images have become inexpensive and ubiquitous. In parallel, the number of people convicted of illegal pornography, especially of child pornography, offences has also risen in many countries. In the United States of America, 1170 child pornography offenders were sentenced in 2007 (Stabenow, 2009); this is a tiny proportion of the population, but nevertheless represents a five-fold increase over 10 years. Courts are also imposing longer prison sentences for child pornography offences; those handed down by courts of the United States of America over the last decade have increased by $443 \%$ to a mean of 7.6 years (Stabenow, 2009). According to the Department of Justice of the United States of America (Department of Justice of the United States of America, 2010) “...child pornography either is growing exponentially or there has been an overwhelming increase in the volume of child pornography images available.” Furthermore, with regard to the main sex exploitation offences referred to the attorneys from 1994 to 2006, the Department of Justice of the Unites States of America (Department of Justice of the United States of America, 2007) reports a shift from sex abuse (73\%) in 1994 to child pornography offences (69\%) in 2006. In this period of time, 82\% of the overall growth in sex exploitation offences were related to child pornography issues.

According to the Ministry of Justice of the United Kingdom (Ministry of Justice of the United Kingdom Statistics bulletin, 2011), the number of convictions for sexual (child) re-offences increased from 20 to 213 within the period from 2000 to 2009. The authors state that this may be the result of a growing number of reconvictions for offences involving indecent photographs of children.

According to the 2011 Annual Report of the Swiss Coordination Unit for Cybercrime Control (Cybercrime Coordination Unit Switzerland, 2012), there has been a decrease in reported cases of illegal pornography use. This was attributed to increasing exchange of pornographic material in secured platforms, such as social networks and closed forums. Nevertheless, child pornography remained the most reported category and $85 \%$ of the consequent criminal prosecutions resulted in convictions for the alleged illegal pornography.

The Internet is a rapidly changing medium. The consequences for future behaviour are not clear, for example, of the growing availability of non-photographic indecent images of children, such as cartoons, tracings and electronically drawn images. In England and Wales as well as in Switzerland, such images are specifically prohibited by law. The Supreme Court of the United States of America did not explicitly address the topic of virtual child pornography in its decision in 2002 (Supreme Court of the United States of America, 2002), but stated that "the Child Pornography Prevention Act of 1996 prohibits speech that records no crime and creates no victims by its production. Virtual child pornography is not 'intrinsically related' to the sexual abuse of children.” Perhaps of even more importance, coming into physical contact by means of the Internet is probably becoming easier and newly developed mobilephone-based applications which allow video-conference and image capture, have a high potential for criminal abuse. Furthermore, the typical users of this technology have changed in the last ten years: In the beginning, access to the Internet required specific knowledge, it was expensive and data transfer rates were very low and slow; now few people in the western world are without easy access to the Internet. As a consequence, consumers of illegal internet pornography, as reported in most studies involving offenders convicted in the last ten years, tend to be offenders who had a higher education if not an academic background, usually aged in their thirties to fifties and socially well integrated (Frei, Erenay, Dittmmann \& Graf, 2005). This group of offenders is likely to be highly sensitive to criminal prosecution and sentencing, with the consequence of low recidivism rate. On the basis of a literature review, Prat and Jonas (Prat \& Jonas, 2013) also characterised most child pornographers as being aged between 25 and 50, without any previous criminal records, well educated, 
in employment and married. Furthermore, the rate was low for re-offending between 1.5 to 6 years after the conviction.

A central concern is the extent to which people convicted of illegal and in particular child pornography offences are likely to commit contact sex offences against children. On the one hand, it is generally accepted that the presence of a deviant sexual preference is correlated with sexual offences (Hanson \& Harris, 1998) and it follows, therefore, that interest in child pornography may also be associated with contact crimes against them. On the other hand, studies that have investigated this topic, including two studies from Canada (Seto \& Eke, 2005; Eke, Seto \& Williams, 2011), two from United Kingdom (Wakeling, Howard \& Barnett, 2011; Webb, Craissati \& Keen, 2007) and one from Switzerland (Endrass et al., 2009) indicate that child pornography offenders have a lower risk of being subsequently convicted of a sexual assault than other child sex offenders. Indeed, the Swiss study of 231 Internet child pornography offenders found no subsequent convictions at all for contact sexual offences over a period of six years, which led the authors to conclude that possessing illegal pornography alone is not an independent risk factor for progression to direct sexual offences against a child.

Seto, Hanson \& Babchishin (Seto, Hanson \& Babchishin, 2011) examined both the criminal histories and recidivism rates of online sexual offenders (especially child pornography offenders) using two meta-analyses. At the time of the index offence, official data showed that $12 \%$ of the online offenders had a contact sexual offence history, whereas unsurprisingly, on the basis of self-reported data, the online sexual offenders showed higher rates of contact sexual offenses (55\%). For recidivism among the online sexual offenders as based on official records, Seto et al. found a total recidivism rate with a sexual offence in general of $4.6 \%, 2.0 \%$ recidivism with a contact sexual offence and 3.4\% for their first child pornography offence. The findings support the assumption of low recidivism rates for contact sexual offence within a particular group of online offenders.

Within a 5-year follow-up of 266 adult male child pornography offenders, Seto \& Eke (Seto \& Eke, 2015) in another study, reported that $11 \%$ committed a new sexual offence, $3 \%$ a new sexual offence against a child and 9\% a new child pornography offence. To predict sexual recidivism among this group of offenders, Seto \& Eke (Seto \& Eke, 2015) developed a risk checklist, Child Pornography Offender Risk Tool (CPORT), which includes seven significant predictors (offender age, prior criminal history, contact sexual offending, failure on conditional release, indication of sexual interest in children, more boy than girl child pornography and other child-related content).

All studies to date have, however, been quite small, and the selected samples in these studies may not be representative of illegal pornography offenders in general.

As the sample of this study represents the complete database of all convicted illegal pornography offenders on one reference day (November $1^{\text {st }} 2008$ ) in Switzerland, it may contribute to the research on this group of offenders with a study of unique size and the simultaneous absence of geographic bias.

Given the increasing number of individuals convicted of illegal and especially child pornography offences, there is an urgent need to understand the relationship between contact and non-contact child sex offences. In particular, it is important for those required to assess and manage risk from such individuals that they should have empirical data to inform clinical assessment.

Therefore, a study was conducted to investigate recidivism in a cohort of convicted illegal pornography offenders using data from a national register. This is by far the largest independent study to date of such offenders. The aims were: 1) to quantify the rate of conviction for contact child sex offences among illegal pornography offenders without previous convictions for child sex offences and 2) to compare offenders convicted of illegal pornography offences alone with dual offenders who-beside illegal pornography offences-were convicted of sexual contact offences against children.

\section{Methods}

\subsection{Study Sample}

The data were extracted from anonymised criminal records from the Federal Office of Justice of Switzerland. From this national database of all criminal convictions registered on one reference day (November $1^{\text {st }} 2008$ ), all cases referring to illegal pornography were selected. Variables were classified as several main groups of offences drawn from the Swiss penal code, but some particularly relevant offences were listed separately. As sex offences play a crucial role in this study, every article of the Swiss penal code concerning sex offences was listed as a single variable. Data were collected by counting and allocating every committed offence (all coded by one author). 
Records in this criminal database are deleted after ten years at the earliest, depending upon the severity of the committed crime. If the perpetrator was placed on parole or sentenced to monetary sanctions, community services, fines or non-suspended custodial sentences of less than 1 year, the records are removed automatically after 10 years. If the sanction consists in non-suspended custodial sentences from 1 to 5 years, the record will be deleted after 15 years and, in the case of a non-suspended custodial sentence over 5 years, it will be removed after 20 years.

Of a total of 4658 cases, 46 were excluded after reconviction analysis, as the reconvictions referred to a crime committed before the time of the first conviction due to illegal pornography. The final cohort was thus of 4612 cases, consisting of 4249 illegal pornography offenders and 363 dual offenders. The first registration for illegal pornography dated from 1973.

\subsection{Measures}

"Illegal pornography offenders" were categorised as anyone convicted of an illegal pornography offence as defined according to Article 197 of the Swiss Penal Code. This includes pornography comprising the depiction of sexual activities involving children, animals, human excrement or violence. Illegal pornographic material may not be produced, put in circulation, advertised, shown or made accessible. Additionally, since 2002, it is prohibited to purchase or to obtain such illegal pornography with the help of electronic media (Swiss Penal Code, 1937). It was not possible in this study to separate out the different categories of pornography, but almost all such convictions would have been for child pornography offences, because the Swiss Coordination Unit for Cybercrime Control has concentrated its efforts for years almost exclusively on the prosecution of child pornography. After transmitting these cases to police authorities, 98\% led to a house search in 2013. Within the confiscated illegal material, most concerns pornography involving children (93\%), followed by pornography with animals (54\%), excrement (39\%) and violence (27\%) (Cybercrime Coordination Unit Switzerland, 2014). Furthermore, clinical forensic assessment shows that child pornography accounts for the vast majority of illegal pornography in convicted Internet pornography offenders (Graf \& Dittmann, 2009).

"Dual offenders" were defined as anyone convicted of Article 187 of the Swiss penal code, or convicted of any sexual offence against children under the age of 16, other than pornography offences. According to Article 187 of the Swiss penal code, it is prohibited to carry out a sexual act involving children aged less than 16 years, or to mislead or involve a child in a sexual act (Swiss Penal Code, 1937). "Other sexual offences" were defined as sexual offences perpetrated against adults, "other violent offences" as all other non-sexual violent offences and "other offences" as those not already categorised. Illegal pornography offenders who were convicted simultaneously of child sexual offences, or had previous convictions of child sexual offences, were categorised as "dual offenders".

The 46 cases excluded from the analysis due to previous offences were proportionally distributed between these two groups of illegal pornography offenders $(n=42,1.0 \%)(n=$ number $)$ and dual offenders $(n=4,1.1 \%)$ $(p=0.781)(p=$ level of significance).

\subsection{Statistical Analysis}

The first registered conviction for illegal pornography was defined as the "index offence". Firstly, records in which there was a minimum observation period of 3 complete years post index offence and censored records at exactly 3 years after the index offence were extracted, yielding a total of 3125 illegal pornography offenders and 297 dual offenders. The 3-year reconviction rates for both illegal pornography offenders and dual offenders were then calculated and compared using the log-rank (Mantel-Cox) test (see Table 1), a nonparametric hypothesis test to compare the survival distributions of two samples. The Chi-square test was used for significance testing for nonparametric continuous and categorical variables. The same approach was applied to determine the 5-year and 10-year reconviction rates.

The reconviction rates of all 4612 records (5.8\% within the illegal pornography offenders, compared to $7.3 \%$ of the dual offenders $(p<0.0001)$ ) for the period up to $1^{\text {st }}$ November 2008 were then compared, regardless of length of post-conviction period, using the Kaplan-Meier method with log-rank (Mantel-Cox) test for significance. Recidivism was defined as any reconviction of a new offence according to the Swiss criminal record if there has been a precedent sentence or an index conviction. All statistical analyses were carried out with SPSS Statistics 19.0 (SPSS, 2010). 
Table 1. 3-year reconviction rates and Log-Rank for total observation time.

\begin{tabular}{|c|c|c|c|c|c|c|}
\hline \multirow{2}{*}{$\begin{array}{l}\text { Category of offence at } \\
\text { reconviction }\end{array}$} & \multicolumn{2}{|c|}{$\begin{array}{l}\text { Illegal pornography offenders } \\
\qquad(\mathrm{n}=3125)\end{array}$} & \multicolumn{2}{|c|}{$\begin{array}{l}\text { Dual offenders } \\
\quad(\mathrm{n}=297)\end{array}$} & \multicolumn{2}{|c|}{$\begin{array}{l}\text { Illegal pornography offenders } \\
\text { compared with dual offenders }\end{array}$} \\
\hline & $\begin{array}{l}\text { Number of } \\
\text { reconvictions }\end{array}$ & $\begin{array}{l}\text { Reconviction } \\
\text { rate in \% } \\
\text { (standard error) }\end{array}$ & $\begin{array}{l}\text { Number of } \\
\text { reconvictions }\end{array}$ & $\begin{array}{l}\text { Reconviction } \\
\text { rate in \% } \\
\text { (standard error) }\end{array}$ & $\begin{array}{c}\text { Log-Rank } \\
\text { (Mantel-Cox) } \\
\text { Chi-Square }\end{array}$ & $p$ \\
\hline Child sexual offences & 7 & $0.2(0.001)$ & 9 & $2.6(0.009)$ & 83.048 & $<0.0001$ \\
\hline Illegal pornography offence & 62 & $1.6(0.002)$ & 12 & $3.5(0.10)$ & 31.576 & $<0.0001$ \\
\hline Other sexual offences & 3 & $0.1(0.000)$ & 3 & $0.9(0.005)$ & 11.453 & 0.001 \\
\hline Other violent offences & 19 & $0.5(0.001)$ & 2 & $0.6(0.004)$ & 2.398 & 0.121 \\
\hline Other offences & 167 & $4.2(0.003)$ & 14 & $4(0.010)$ & 1.477 & 0.224 \\
\hline Total & 230 & $5.8(0.004)$ & 26 & $7.3(0.014)$ & 14.074 & $<0.0001$ \\
\hline
\end{tabular}

\subsection{Ethics}

The Swiss Federal Office of Justice approved the study and permitted access to anonymised data from the Federal Criminal Record for the purpose of this study.

\section{Results}

\subsection{Comparison of Offending Rates over a 3-Year Period Following an Index Conviction}

Of a total of 4612 offenders, 4249 were illegal pornography offenders and 363 were dual offenders, of whom 3125 and 297, respectively, were available for 3-year follow-up.

Two hundred and thirty (230) (5.8\%) illegal pornography offenders were convicted of any further offence during the follow-up period, compared with $26(7.3 \%)$ dual offenders $(p<0.0001)$. As presented in Table 1 illegal pornography offenders were significantly less likely to be reconvicted of any offence in the period than dual offenders. These figures represent a 3-year reconviction rate for an illegal pornography offence among illegal pornography offenders of $1.6 \%$, which is significantly less than that for dual offenders, who showed a reconviction rate of $3.5 \%(p<0.0001)$.

Just seven (0.2\%) illegal pornography offenders were convicted of a contact child sex offence within 3 years. This compared to 9 (2.6\%) dual offenders $(p<0.0001)$. Table 1 also shows that illegal pornography offenders were significantly less likely to commit a contact child sexual offence during the follow-up period than the dual offenders.

Very few of either group were convicted of sexual offences against adults (3 illegal pornography offenders, 3 dual offenders). Even so, it was again significantly less likely that the illegal pornography group became contact offenders for other sexual offences than the dual offenders $(p=0.001)$. Similarly, violent offences were unusual, and this time did not differentiate the groups. Non-sexual and non-violent offences were fairly common in both groups, accounting for $4.2 \%$ of the illegal pornography group and $4 \%$ of the dual offenders $(p=0.224)$.

\subsection{Comparison of Offending Rates Concerning Child Sexual Offences over a 5- and a 10- Year Period Following an Index Conviction}

Table 2 shows the reconviction rates for child sexual offences among the illegal pornography offenders after a 5-year observation period which was $0.2 \%$ and did not differ from the values after a 3-year observation period. Furthermore, only a slight increase can be documented within this group of offenders after a 10-year observation period (reconviction rate of $0.5 \%$ ).

In contrast, the reconviction rate for the dual offenders for child sexual offences after a 5-year observation time was 3.3\%, which was an increase over the corresponding figure after 3 years (2.6\%). This value increased to $6.4 \%$ after 10 years. Thus, dual offenders are more likely than illegal pornography offenders to commit a child sexual offence during the follow-up period. 


\subsection{Comparison of All Offenders with an Index Illegal Pornography or Contact Sexual Offence for the Entire Record}

The median observation time for dual offenders was significantly longer than that for the illegal pornography offenders, (6.9 years, range 0.7 to 31.3 years, compared with 5.4 years, range 0.3 to 31.8 years, $(p<0.001)$ ). As the median observation times between the two groups differed significantly (longer observation times for the dual offenders), the control for observation time was carried out using the Kaplan-Meier Method.

Kaplan-Meier survival analysis depicted in Figure 1 shows a clear difference between reconviction rates of illegal pornography and dual offenders, which was highly significant (log-rank Mantel-Cox, $p<0.001$ ).

\section{Discussion}

Convicted illegal pornography offenders are, thus, not immune to reconvictions, but within an observation period of 3 years their rate of reconviction is about 5.8\%, significantly lower than that of convicted dual offenders (7.3\%). Furthermore, while nearly two-thirds of the illegal pornography offenders' new crimes have nothing to do with sexual or violent offending, about half of the new crimes of convicted dual offenders were of a sexual (mainly) or violent nature. Less than 1\% of illegal pornography offenders progress to contact child sexual crimes within three, five and ten years and, indeed, only 1.6\% prove to be recidivist illegal pornography offenders after 3 years. Survival analysis and the calculation of 5- and 10-year reconviction rates showed that the respective recidivism rates still climbed up to ten years after the index offence, which underlines the importance of adequately long observation times in studies about recidivism rates in child abuse.

Table 2. 5- and 10-year reconviction rates.

\begin{tabular}{|c|c|c|c|c|}
\hline \multirow{2}{*}{$\begin{array}{l}\text { Category of offence at } \\
\text { reconviction }\end{array}$} & \multicolumn{2}{|c|}{ Illegal pornography offenders } & \multicolumn{2}{|c|}{ Dual offenders } \\
\hline & $\begin{array}{l}\text { Number of } \\
\text { reconvictions }\end{array}$ & $\begin{array}{l}\text { Reconviction rate in \% } \\
\text { (standard error) }\end{array}$ & $\begin{array}{l}\text { Number of } \\
\text { reconvictions }\end{array}$ & $\begin{array}{l}\text { Reconviction rate in \% } \\
\text { (standard error) }\end{array}$ \\
\hline $\begin{array}{l}\text { Child sexual offences after } \\
5 \text { years observation time }\end{array}$ & 8 & $0.2(0.001)$ & 11 & $3.3(0.010)$ \\
\hline $\begin{array}{l}\text { Child sexual offences after } \\
10 \text { years observation time }\end{array}$ & 10 & $0.5(0.003)$ & 17 & $6.4(0.016)$ \\
\hline
\end{tabular}

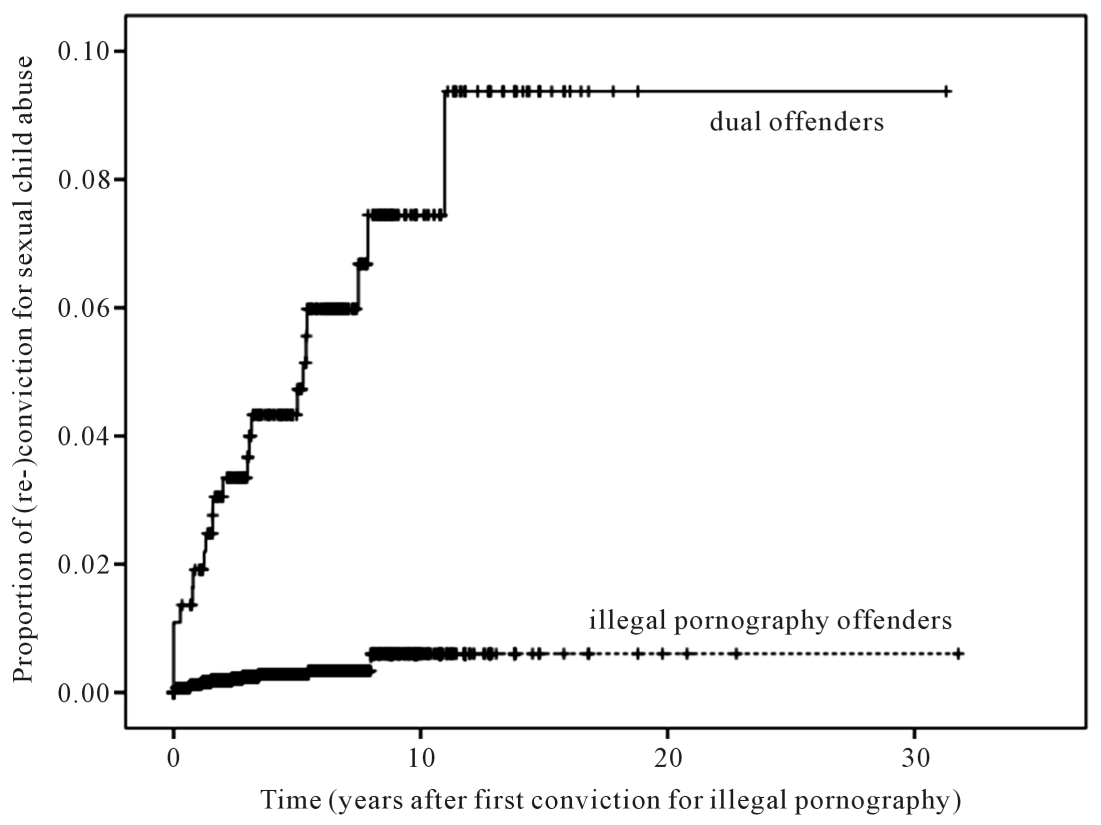

Figure 1. Kaplan-Meier survival analysis for reconviction for sexual child abuse. Illegal pornography offenders were less likely to be convicted for sexual child abuse. 
The findings on the progression from illegal pornography, in particular from child pornography, to contact child sexual offences are consistent with results and hypotheses from prior studies (Seto \& Eke, 2005; Webb, Craissati \& Keen, 2007; Endrass et al., 2009), which showed that illegal pornography offenders were significantly less likely to be reconvicted, either generally or sexually.

A follow-up study (Seto \& Eke, 2005) with an average follow-up of 4.1 years, examined the future offences of a total of 541 child pornography offenders. This revealed an overall recidivism rate of $32 \%$, in which $4 \%$ of the child pornography offenders were charged with a new contact sex offence (for example sexual assault or sexual interference), but 7\% were charged again with child pornography offenses.

The cohort was larger than in previous studies, corresponding to a complete national sample for the period. This study strengthens the assumption that illegal pornography offenders were significantly less likely to be convicted of a further illegal pornography offence, and, indeed, had a generally much lower recidivism rate than dual offenders.

The figures for reconviction rates for any offence in this study—even for dual offenders—-may be considered low but are consistent with results from longitudinal studies, such as that from Idaho by Patrick \& Marsh (Patrick \& Marsh, 2009). This study showed over a period of 13 years that reconviction rates for child sexual offenders for any felony was $13.6 \%$, and for child sexual offences the rate was $9.2 \%$. The prior Swiss study (Endrass et al., 2009) of 231 convicted Internet child pornography offenders found an overall reconviction rate of $3 \%$, a rate of $2.6 \%$ for illegal pornography and $0.4 \%$ for bodily harm. None of the Internet child pornography offenders were reconvicted for a physical sexual offence.

Data from the Swiss Federal Statistic Office revealed a slight decrease in convictions of illegal pornography over a period of 5 years (2005: 58\%, 2010: 53\%), whereas the conviction rate involving a sexual act with a child are overall constant (2005: 28\%, 2010: 29\%), compared to the overall sex offences (Swiss Federal Office of Statistics, 2014).

One of the major findings from the present study is the relatively low "progression rate" for those convicted of illegal pornography offences, predominantly of child pornography offences, to contact child sex offences. Still, ten of a total of 4249 consumers of illegal pornography were later reconvicted for having sexually abused children, and it would be important to try and identify the small minority at such risk. It is of course possible that the reconviction rate is smaller than the true offence rate. For example, in a Dutch study of child pornography offenders who were subjected to a polygraph examination, 21 of the 38 individuals who were examined and who had all denied any form of contact sexual offending behaviour towards children in their self-report, disclosed during the polygraph test that they had in fact committed contact sexual offences on children, including penetration, penile masturbation and fondling (Buschman \& Bogaerts, 2009). A more recent study from the same group in a similar sample of 24 offenders found significantly more high-risk behaviour to children disclosed in a polygraph examination but did not report contact offences (Buschman et al., 2010).

Two studies examined the validity of existing actuarial risk assessment tools for predicting recidivism of Internet sexual offenders: Wakeling, Howard, \& Barnett (Wakeling, Howard, \& Barnett, 2011) from the National Offender Management Service, London, United Kingdom, found very low reoffending rates in a sample of 1344 Internet sexual offenders and moderate to very good predictive accuracy using receiver operating characteristics statistics (Area under the curve between 0.67 and 0.87). Furthermore, Webb, Craissati, \& Keen (Webb, Craissati, \& Keen, 2007) using Stable 2000 (Hanson \& Harris, 2001) and Risk Matrix 2000 (Thornton et al., 2003) for Internet sexual offenders stated that the Stable 2000 may be applicable for predicting general sexually risky behaviour among Internet offenders, but also emphasised the lack of a risk measure predicting risk of failure for the corresponding group of offenders.

\section{Conclusion}

The consumption of illegal pornography, especially of child pornography alone, if not associated with other offensive behaviour, problematic personality traits, or substance abuse appears to be a weak predictor of future child sexual abuse. Future studies should try to link quantitative data from cohorts with more detailed qualitative characteristics of offenders to develop a typology relevant for risk assessment as well as early preventive intervention.

As possible limitations of this study we might suggest that findings were expressed without taking into account possible variations in "time at risk". A few offences may be committed even while serving a prison sentence 
or residing in a secure hospital, but, as child visits are strictly controlled in such institutions, Internet access strictly limited and the content of material sent or brought into the institutions is screened, illegal pornography offenders or contact sexual offenders generally need access to the wider community in order to be able to offend. In this context, it would make sense to consider time at risk to be time in the community, however, the decision was made not to attempt to calculate this because the study relies on records and only the most basic assumptions can be made about the length of time served in prison after a custodial sentence has been passed. In fact, any bias in this context would have increased the risk of reoffending for the illegal pornography offenders. In Switzerland, the punishment for consumption of illegal pornography is usually a fine in combination with a conditional discharge even for re-offences of such crimes. In contrast, prison sentences are not uncommon or are the rule for contact child sex offenders. Thus, the illegal pornography offenders were likely to have had greater time at risk for recidivism or new offences, and yet their further rates of offence were consistently lower in respect of child related and of other offences than those of the dual offenders.

Due to the main emphasis on the likelihood of an escalation from consuming illegal and in particular child pornography in the Internet to a child contact offence, the focus was consciously on the comparison of illegal pornography offenders without conviction of a sexual contact crime and the dual offenders. To generate a more robust risk ratio subsequent studies are planned to include a third comparison group of contact offenders without any pornography convictions.

Another major limitation consists in the lack of any demographic or personal features, as criminal records were completely anonymised, which is why it was impossible to identify potential predictor variables or apply actuarial risk scales (for example Static-2002 (Hanson \& Thornton, 2003)). Furthermore, by collecting the data from criminal records, it was not apparent precisely for what category of illegal pornography (depiction of sexual activities involving children, animals, human excrements or violence) the offender had been convicted. However, the Swiss Coordination Unit for Cybercrime Control (Cybercrime Coordination Unit Switzerland, 2014) considers that the majority of the material is about illegal pornography involving children.

\section{Acknowledgements}

We want to express our gratitude to the Swiss Federal Office of Justice for approving the study and permitting access to data from the Federal Criminal Record for the purpose of this study. We also thank Marlon Pflüger (Forensic Psychiatric Hospital, Psychiatric Hospital of the University of Basel) for support in statistics.

\section{Competing Interests}

The authors declare that they have no competing interests.

\section{Authors' Contributions}

Manuscript writing, as well as acquisition and interpretation of data was led by AG with direct supervisory support and comment of MG. RJ drafted the manuscript and conducted statistically analyses. VD made contributions to the conception of the study. PT was involved in drafting and critical editing of the manuscript. MG oversaw data collection and substantially contributed to design and revision for important intellectual content. All authors read an approved the final manuscript.

\section{References}

Buschman, J., \& Bogaerts, S. (2009). Polygraph Testing Internet Offenders. In The Use of Polygraph in Assessing, Treating and Supervising Sex Offenders: A Practitioner's Guide (pp. 113-128). Chichester: John Wiley \& Sons. http://dx.doi.org/10.1002/9780470743232.ch7

Buschman, J., Bogaerts, S., Foulger, S., Wilcox, D., Sosnowski, D., \& Cushman, B. (2010). Sexual History Disclosure Polygraph Examinations with Cybercrime Offences: A First Dutch Explorative Study. International Journal of Offender Therapy and Comparative Criminology, 54, 395-411. http://dx.doi.org/10.1177/0306624X09334942

Cybercrime Coordination Unit Switzerland (2012). Annual Report 2011. http://www.cybercrime.admin.ch/content/dam/data/kobik/Berichte/2008-12/rechenschaftsbericht-2011-d.pdf

Cybercrime Coordination Unit Switzerland (2014). Annual report 2013. https://www.cybercrime.admin.ch/dam/data/kobik/Berichte/2014-18/rechenschaftsbericht-2013-d.pdf 
Department of Justice of the United States of America (2007). Federal Prosecution of Child Sex Exploitation Offenders, 2006. http://www.bjs.gov/content/pub/pdf/fpcseo06.pdf

Department of Justice of the United States of America (2010). The National Strategy for Child Exploitation Prevention and Interdiction. http://www.justice.gov/psc/docs/natstrategyreport.pdf

Eke, A. W., Seto, M. C., \& Williams, J. (2011). Examining the Criminal History and Future Offending of Child Pornography Offenders: An Extended Prospective Follow-Up Study. Law and Human Behavior, 35, 466-478. http://dx.doi.org/10.1007/s10979-010-9252-2

Endrass, J., Urbaniok, F., Hammermeister, L. C., Benz, C., Elbert, T., Laubacher, A., \& Rossegger, A. (2009). The Consumption of Internet Child Pornography and Violent and Sex Offending. BMC Psychiatry, 9, 4. http://dx.doi.org/10.1186/1471-244X-9-4

Frei, A., Erenay, N., Dittmmann, V., \& Graf, M. (2005). Paedophilia on the Internet-A Study of 33 Convicted Offenders in the Canton of Lucerne. Swiss Medical Weekly, 135, 488-494.

Graf, M., \& Dittmann, V. (2009). Internet Sex Offending-Psychological Features and Criminal Risks. Forensische Psychiatrie, Psychologie und Kriminologie, 3, 99-106. http://dx.doi.org/10.1007/s11757-009-0130-z

Hanson, R. K., \& Harris, A. (1998). Dynamic Predictors of Sexual Recidivism. Public Works and Government Services Canada. https://www.ipce.info/library_2/han/hanson_dynamic_text.PDF

Hanson, R. K., \& Harris, A. J. R. (2001). A Structured Approach to Evaluating Change among Sexual Offenders. Sexual Abuse, 13, 105-122. http://dx.doi.org/10.1023/A:1026600304489

Hanson, R. K., \& Thornton, D. (2003). Notes on the Development of the Static-2002. Public Works and Government Services Canada. http://www.publicsafety.gc.ca/cnt/rsrcs/pblctns/nts-dvlpmnt-sttc/nts-dvlpmnt-sttc-eng.pdf

IBM Corp. Released (2010). IBM SPSS Statistics for Windows, Version 19.0. Armonk, NY: IBM Corp.

Ministry of Justice of the United Kingdom Statistics Bulletin (2011). Adult Re-Convictions: Results from the 2009 Cohort. England and Wales.

http://webarchive.nationalarchives.gov.uk/20120104233117/http:/www.justice.gov.uk/downloads/publications/statistics-a nd-data/mojstats/adult-reoffending-statistics-09.pdf

Patrick, S., \& Marsh, R. (2009). Recidivism among Child Sexual Abusers: Initial Results of a 13-Year Longitudinal Random Sample. Journal of Child Sexual Abuse, 18, 123-136. http://dx.doi.org/10.1080/10538710902743909

Prat, S., \& Jonas, C. (2013). Psychopathological Characteristics of Child Pornographers and Their Victims: A Literature Review. Medicine, Science and Law, 53, 6-11. http://dx.doi.org/10.1258/msl.2012.011133

Seto, M. C., \& Eke, A. W. (2005). The Criminal Histories and Later Offending of Child Pornography Offenders. Sexual Abuse, 17, 201-210. http://dx.doi.org/10.1007/s11194-005-4605-y

Seto, M. C., \& Eke, A. W. (2015). Predicting Recidivism among Adult Male Child Pornography Offenders: Development of the Child Pornography Offender Risk Tool (CPORT). Law and Human Behavior, 39, 416-429. http://dx.doi.org/10.1037/lhb0000128

Seto, M. C., Hanson, R. K., \& Babchishin, K. M. (2011). Contact Sexual Offending by Men With Online Sexual Offenses. Sexual Abuse, 23, 124-145. http://dx.doi.org/10.1177/1079063210369013

Stabenow, T. (2009). Deconstructing the Myth of Careful Study: A Primer on the Flawed Progression of the Child Pornography Guidelines. http://www.fd.org/docs/Select-Topics---sentencing/child-porn-july-revision.pdf

Supreme Court of the United States of America (2002). Ashcroft v. Free Speech Coalition. http://caselaw.lp.findlaw.com/scripts/getcase.pl?court=US\&vol=000\&invol=00-795

Swiss Federal Office of Statistics (2014). http://www.bfs.admin.ch/bfs/portal/de/index/themen/19/03/03/key/ueberblick/01.html

Swiss Penal Code (1937). http://www.admin.ch/opc/de/classified-compilation/19370083/index.html

Thornton, D., Mann, R., Webster, S., Blud, L., Travers, R., Friendship, C., \& Erikson, M. (2003). Distinguishing and Combining Risks for Sexual and Violent Recidivism. Annals of the New York Academy of Sciences, 989, 225-235. http://dx.doi.org/10.1111/j.1749-6632.2003.tb07308.x

Wakeling, H. C., Howard, P., \& Barnett, G. (2011). Comparing the Validity of the RM2000 Scales and OGRS3 for Predicting Recidivism by Internet Sexual Offenders. Sexual Abuse, 23, 146-168. http://dx.doi.org/10.1177/1079063210375974

Webb, L., Craissati, J., \& Keen, S. (2007). Characteristics of Internet Child Pornography Offenders: A Comparison with Child Molesters. Sexual Abuse, 19, 449-465. http://dx.doi.org/10.1007/s11194-007-9063-2 